\title{
The Effects of Separate and Combined Use of PGF2 $a$ and GnRH Hormones and the Addition of Beta-Carotene on Fertility Parameters in Dairy Cows with Ovarian Cysts
}

\author{
Birten Emre', İbrahim Küçükaslan², Ali Reha Ağaoğlu³, Serhan Serhat Ay4, \\ Duygu Kaya ${ }^{5}$, Mustafa Somali ${ }^{6}$ \& Selim Aslan ${ }^{7}$
}

\begin{abstract}
Background: Ovarian cysts are commonly observed pathologies, which interfere with normal cyclic activity and adversely affect fertility in cows. Beta-carotene is effective in the reduction of reproductive problems by inducing the natural defence mechanisms of the body. There are several methods that can be used for the treatment of ovarian cysts. The separate and combined use of GnRH and PGF2 $\alpha$ commonly uses in the treatment of ovarian cysts. Therefore, in the presented study the effects of Beta-carotene ( $\beta C$ ) addition for the treatment of ovarian cysts either with GnRH solely or GnRH and PGF2 $\alpha$ in combination on the fertility parameters of dairy cows were investigated.

Materials, Methods \& Results: Seventy-six Holstein Friesian cows having ovarian cysts diagnosed by ultrasonography (USG) were divided into three groups. Cows in Group I (GI, $\mathrm{n}=27$ ), were injected with GnRH (Buserelin acetate, $5 \mathrm{~mL}$, im), PGF2 $\alpha$ (Tiaprost-trometamol, $5 \mathrm{~mL}$, im) and $\beta \mathrm{C}$ ( $20 \mathrm{~mL} / \mathrm{cow}$, into 4 regions by im route). In Group II (GII, $\mathrm{n}=25)$ GnRH (Buserelin acetate, $5 \mathrm{~mL}$, im) and PGF2 $\alpha$ (Tiaprost-trometamol, $5 \mathrm{~mL}$, im) were administrated while GnRH (Buserelin acetate, $5 \mathrm{~mL}$, im) solely in Group III (GIII, $\mathrm{n}=24)$. Cysts were monitored via USG, and blood samples were collected on the on day of treatment (day 0 ) and on the 7th and 14th days following the administrations. Cows shoving oestrous were inseminated and pregnancy diagnoses were performed on the 40th day following insemination. Treatment results showed that there were statistically no significant differences between GI and GII $(P>0.05)$. Only numerical difference obtained in time from therapy to pregnancy and overall pregnancy index $(P>0.05)$. Overall pregnancy rate $(85 \%)$, first service pregnancy rates $(40 \%)$ and overall pregnancy index (2.11) in GI were found significantly higher than GIII $(53.3 \% ; 20 \%$; 4.12) $[P<0.05]$. No significant difference was observed in progesterone $(\mathrm{P} 4)$ levels between the groups $(P>0.05)$. It was found that $\beta C$ administrations significantly increased $\beta C$ levels in GI than GII and GIII on the $7^{\text {th }}$ and $14^{\text {th }}$ days $(P<0.05)$. Discussion: One of the most common problems encountered in modern dairy production is the development of ovarian cysts. Treatments for ovarian cyst are numerous and variable, and have changed considerably over the years. In the present study, GnRH and PGF2 $\alpha$ were administered together as a combination, and as a result of this combined use, higher percentages were obtained for both pregnancy rate and fertility parameters in GI and GII, in comparison to the group administered with GnRH alone (GIII). Better outcome from combination therapy (GnRH and PGF2 $\alpha$ ) may be due to the fact that luteal thickening in the walls of cysts was determined by ultrasonography, but P4 values were not identified immediately and the treatments were not categorized in accord with these values. No statistically significant differences were determined between GI and GII concerning the fertility parameters investigated, however numerical and proportional differences were observed. $\beta C$ levels were significantly higher on day 7 and 14 after treatment in GI which were administered $\beta C$ additionally to the treatment protocol for ovarian cysts. This statistical difference suggests that administration of $\beta C$ in combination therapy is also effective in the treatment of ovarian cysts. In conclusion, it was determined that high pregnancy rates were obtained by the combined treatment of ovarian cysts $(\mathrm{GnRH}+\mathrm{PGF} 2 \alpha)$ and number of inseminations per conception were at desired limits. Better percentile and numerical fertility parameters were achieved in the group, which additionally received $\beta C$, high numbers of infertility cases, $\beta C$ supplementation could be a viable option for treatment.
\end{abstract}

Keywords: dairy cows, ovarian cysts, GnRH, PGF2 $\alpha$, $\beta$-carotene. FVM, Dicle University, Diyarbakır, Turkey. ${ }^{3}$ Dep. O \& G, FVM, Mehmet Akif Ersoy University, Burdur, Turkey. ${ }^{4}$ Dep. O \& G, FVM, Ondokuz May1s University, Samsun, Turkey. ${ }^{5}$ Dep. O \& G, FVM, Kafkas University, Kars, Turkey. ${ }^{6}$ Süt Kardesler Süt ve Süt Urn, Izmir, Turkey. ${ }^{7}$ Dep. O \& G, FVM, Near East University, Nicosia, Turkey. CORRESPONDENCE: B. Emre [birten@ gmail.com - Fax: +90 (414) 3183922]. Department of Obstetrics and Gynecology, Faculty of Veterinary Medicine, Harran University. 63200 Sanliurfa, Turkey. 


\section{INTRODUCTION}

Ovarian cysts are commonly observed pathologies, which interfere with normal cyclic activity and adversely affect fertility in cows. Due to the prolonged calving interval, culling of the animals and veterinary medical costs, ovarian cysts have economic significance for dairy industry [46]. It is reported that the incidence of ovarian cysts in herds ranges between 6 $\%$ and $30 \%[25,40,42]$.

Bovine ovarian cysts are fluid-filled, anovulatory, pathological follicles with a diameter of $\geq 25 \mathrm{~mm}$, which are observed in either one or both of the ovaries and persist for more than 10 days in the absence of active luteal tissue $[40,42,46]$. It is generally accepted that cystic follicles develop as a result of the functional disorders of the hypothalamo-hypophyseal-ovarian axis [25,31,46]. Local factors, including among others, nutrition, uterine infections, stress and genetics are involved in the development of this disorder $[25,31,46]$. One of the major factors involved is $\beta C$ deficiency $[10,13]$. Beta-carotene as the precursor of Vitamin $A, \beta C$ is effective in the reduction of reproductive problems by inducing the natural defence mechanisms of the body through lymphocyte proliferation and phagocytosis [12]. The gonadotropin-releasing hormone $(\mathrm{GnRH})$, intravaginal progesterone devices $\left(\mathrm{PRID}^{\circledR}\right.$ or CIDR) and prostaglandin F2 $\alpha$ have been commonly used in the treatment of ovarian cysts $[7,31,40]$. Successful fertility results have been reported when $\mathrm{GnRH}$ administrations were combined with $\beta C$, used for the early postpartum treatment of ovarian cysts [1].

This study was designed to investigate the effects of separate or combined use of GnRH and PGF $2 \alpha$ or the addition of Beta-carotene to this regimen, for the treatment of ovarian cysts, on fertility parameters.

\section{MATERIALS AND METHODS}

\section{Animals}

Seventy-six Holstein-Friesian dairy cows, aged between 3 to 7 years, have constituted the animal material of the study. The study was conducted at a private dairy farm, where the cows were housed in semi-open free-stall barns throughout the year and fed on a total mixed ration (corn and grass silage, hay, triticale, canola and a balanced grain ration) twice a day.

Study design

It was determined that the body condition scores of the animals included in the study ranged be- tween 3.0 and 3.5 (5 point-scale) and that their average milk yield per lactation ranged from 7.110 to 11.000 $\mathrm{kg}$. Throughout the herd, in which regular postpartum examinations were held, the animals that did not show oestrus between days 25-35, 45-50 and 60-70 postpartum and those that either showed oestrus or did not conceive after being inseminated were allocated for the further examinations with ultrasonography (USG).

The animals were examined for the presence of ovarian cysts by USG (linear probe; 5.0 Mhz, Agroscan $\left.{ }^{\circledR} \mathrm{L}\right)^{1}$ and were assigned to three groups on the basis of the results obtained (diameter of follicular structure $\geq 2.5 \mathrm{~cm}$; for a minimum ten days in the absence of a luteal tissue) [42,46]. The cows in Group I $(\mathrm{GI}, \mathrm{n}=27)$ were administered with $\mathrm{GnRH}(5 \mathrm{~mL} /$ cow im) [Buserelin acetate; Buserin $\left.{ }^{\circledR}\right]^{2}, \mathrm{PGF} 2 \alpha(5 \mathrm{~mL} /$ cow, im) [Tiaprost-trometamol; Iliren $\left.{ }^{\circledR}\right]^{3}$, and $\beta C(20$ $\mathrm{mL} / \mathrm{cow}$, into 4 regions by im route) [Carofertin $\left.{ }^{\circledR}\right]^{4}$. GnRH (Buserelin acetate; Buserin ${ }^{\circledR}, 5 \mathrm{~mL} /$ cow im) and PGF2 $\alpha$ (Tiaprost-trometamol; Iliren ${ }^{\circledR}, 5 \mathrm{~mL} / \mathrm{cow}$, im) were administrated to the animals in Group II (GII, $\mathrm{n}=25$ ). Group III (GIII, $\mathrm{n}=24$ ) was maintained for control purposes and received only GnRH (Buserelin acetate; Buserin ${ }^{\circledR}, 5 \mathrm{~mL} / \mathrm{cow}$ im). The progression of the ovarian cysts was checked on the day of administration (day 0) and once a week for the following two weeks (days 7 and 14) [by USG].

The size and type (luteal, follicular) of the ovarian cysts detected at examination were written down in follow-up forms. The animals, which were having signs of oestrus as a result of cystic regression, were inseminated. Pregnancy examinations were performed 40-45 days after insemination by transrectal ultrasonography. The overall pregnancy rates were determined according to the results of the three inseminations performed in the postpartum period. Cows, displaying signs of oestrus after the third insemination, were considered as non-pregnant.

Cysts with $>3 \mathrm{~mm}$ wall thickness and $>3.18$ $\mathrm{nmol} / \mathrm{L}$ serum progesterone $(\mathrm{P} 4)$ were considered to be luteal cysts, whilst cysts that had a thinner wall and lower serum P4 levels were considered to be follicular cysts $[23,33]$.

For the assessment of treatment efficiency, fertility parameters including the time from therapy to first service (day), time from therapy to pregnancy (day), as well as the overall pregnancy rate (pregnancy rates after a maximum of three consequent insemina- 
tions, \%), first service pregnancy rates (pregnancy rates after first insemination, \%), insemination index, the pregnancy index (number of services per pregnancy) and overall pregnancy index (number of inseminations in all animals/pregnant animals) and treatment success rate $(\%)$ were investigated [35].

\section{Blood sampling and testing}

In order to measure the progesterone (P4) and $\mathrm{C}$ levels, $10 \mathrm{~mL}$ blood samples were taken from the jugular vein of each animal both before treatment and on the control days after treatment. The blood samples were centrifuged at $850 \mathrm{~g}$ for $15 \mathrm{~min}$ and the sera extracted were stored at $-20^{\circ} \mathrm{C}$ until being analysed.

Beta-carotene concentrations were determined using the spectrophotometric method [34]. Serum P4 concentrations were measured with the electrochemical immunoassay (Düzen Laboratory Group)5 [41].

\section{Statistical analysis}

The statistical analysis were made by using the SPSS ${ }^{\circledR}$ (Statistical Package for the Social Sciences, $16.0)^{6}$ software. The homogeneity of the groups was investigated with the Kolmogorov-Smirnov test. The groups displaying homogenous distribution were compared with the analysis of variance (Tukey's test). On the other hand, the groups not displaying a homogenous distribution were investigated by using the MannWhitney $\mathrm{U}$ test, and those that were determined to be different were compared with Wilcoxon's test. A level of $P<0.05$ was considered statistically significant.

\section{RESULTS}

During the study period, 76 of investigated 557 cows were determined to have ovarian cysts and were treated. Of the cysts detected at examination, 31 were follicular cysts $(40.8 \%)$ and $45(59.2 \%)$ were luteal cysts. The incidence of ovarian cysts in the herd was ascertained to be $13.6 \%$. Ultrasonography (wall thickness $\leq 3 \mathrm{~mm} ;>3 \mathrm{~mm}$ ) and P4 measurements (> 3.18 $\mathrm{nmol} / \mathrm{L}$ ) showed that the percentage of the luteal cysts was higher than follicular cysts (Table 1).

In 23 of 27 cows in GI regression of the cysts were determined and 20 (74\%) cows showed oestrus. In GII 20 (80\%) of 25 cows with ovarian cysts showed oestrus and inseminated. In GIII, out of the 24 cows with an ovarian cyst, $15(62.5 \%)$ were determined to show oestrus and were inseminated. Regression of the cysts after treatment was observed in 3 of 7 cows $(42.85 \%)$ in GI, 2 of 5 cows (40\%) in GII and 3 of 9 $(33.3 \%)$ in GIII in non-inseminated cows (Table 2).

Table 1. The incidence of ovarian cysts types in the herd.

\begin{tabular}{ccccc}
\hline Type of cyst & G I (n) & G II (n) & G III (n) & Total \\
\hline Folliculer cyst & 8 & 8 & 15 & 31 \\
Luteal cyst & 19 & 17 & 9 & 45 \\
Total & 27 & 25 & 24 & 76 \\
\hline
\end{tabular}

Table 2. Percentages of cystic regression after treatment.

\begin{tabular}{|c|c|c|c|c|c|}
\hline \multicolumn{2}{|c|}{ Ovarian cyst } & G I (n) & G II (n) & G III (n) & Total \\
\hline \multirow{2}{*}{$\begin{array}{l}\text { Regression } \\
\qquad(+)\end{array}$} & Insemination $(+)$ & 20 & 20 & 15 & 55 \\
\hline & Insemination (-) & 3 & 3 & 3 & 9 \\
\hline \multicolumn{2}{|l|}{ Regression (-) } & 4 & 2 & 6 & 12 \\
\hline \multicolumn{2}{|c|}{ Total } & 27 & 25 & 24 & 76 \\
\hline
\end{tabular}


No significant difference was determined between the fertility results of GI and GII $(P>0.05)$. Only numerical differences were observed in terms of time from therapy to pregnancy (DT-PD) and overall pregnancy index $(P>0.05)$. It was determined that the overall pregnancy rates (OPR), overall pregnancy index (OPI), and treatment success rate (TSR) of GI significantly differed from the same parameters of GIII $(P<0.05)$. Numerical differences were determined between GI and GII in terms of all evaluated fertility parameters. It was determined that lower number of inseminations were performed in GI for the conception of the animals (Table 3).
In GI serum $\beta \mathrm{C}$ concentrations increased till to the last sampling on day 14 after treatment. On days 7 and 14 after treatment serum $\beta C$ levels of GI were significantly higher than GII and GIII $(P<0.05)$ [Table 4].

The assessment of the $\mathrm{P} 4$ levels of the inseminated cows demonstrated that, in GI, the activity of the ovaries with cysts producing low P4 levels on day 0 ( $\leq$ $3.18 \mathrm{nmol} / \mathrm{L})$ and high P4 levels on day 7 (6.18 - 24.63 $\mathrm{nmol} / \mathrm{L}$ ) was $75 \%$ (associated with decrease / increase in P4 levels), whilst in the other groups the ovarian activity rate was determined as $40 \%$ on day $7(P<0.05)$. In $60 \%$ of the cows in GII and GIII regression of the ovarian cysts prolonged to a period of 14 days (Table 5).

Table 3. The fertility parameters of the cows with ovarian cysts in groups*.

\begin{tabular}{cccc}
\hline Fertility parameters & G I & G II & G III \\
\hline PD & $113.66 \pm 99.10^{\mathrm{a}}$ & $96.08 \pm 45.37^{\mathrm{a}}$ & $77.26 \pm 34.11^{\mathrm{a}}$ \\
DT-FS (day) & $39.7 \pm 26.07^{\mathrm{a}}$ & $42.6 \pm 23.3^{\mathrm{a}}$ & $31.20 \pm 21.04^{\mathrm{a}}$ \\
FSPR (\%) & $40(8 / 20)^{\mathrm{a}}$ & $30(6 / 20)^{\mathrm{a}}$ & $20(3 / 15)^{\mathrm{b}}$ \\
DT-PD (day) & $69 \pm 37.34^{\mathrm{a}}$ & $76.64 \pm 42.18^{\mathrm{a}}$ & $64.87 \pm 38.29^{\mathrm{a}}$ \\
OPR (\%) & $85(17 / 20)^{\mathrm{a}}$ & $70(14 / 20)^{\mathrm{a}, \mathrm{b}}$ & $53.3(8 / 15)^{\mathrm{b}}$ \\
INI & $1.8(36 / 20)$ & $2.0(40 / 20)$ & $2.3(33 / 14)$ \\
PI & $1.76(30 / 17)$ & $1.78(25 / 14)$ & $1.75(15 / 8)$ \\
OPI & $2.11(35 / 17)^{\mathrm{a}}$ & $2.85(40 / 14)^{\mathrm{a}, \mathrm{b}}$ & $4.12(33 / 8)^{\mathrm{b}}$ \\
TSR (\%) & $62.96(17 / 27)^{\mathrm{a}}$ & $56.0(14 / 25)^{\mathrm{a}, \mathrm{b}}$ & $33.3(8 / 24)^{\mathrm{b}}$ \\
\hline
\end{tabular}

*Data of inseminated animals. PD: Postpartum day, DT-FS: time from therapy to first service; day, FSPR: first service pregnancy rates, DT-PD: time from therapy to pregnancy; day, OPR: overall pregnancy rates, INI: insemination index, PI: pregnancy index, OPI: Overall pregnancy index, TSR: Treatment success rate. n.s.: Non-significant $(P>0.05)$, Values with different superscripts $(\mathrm{a}, \mathrm{b})$ in the same row are significantly different $(P<0.05)$.

Table 4. The Beta-carotene levels of the cows with ovarian cysts in groups $(\mu \mathrm{g} / \mathrm{dL})$.

\begin{tabular}{|c|c|c|c|}
\hline \multicolumn{4}{|c|}{$\begin{array}{l}\text { Beta-carotene } \\
(\mu \mathrm{g} / \mathrm{dL}) \pm \mathrm{SV}\end{array}$} \\
\hline Group & $0^{\text {th }}$ day & $7^{\text {th }}$ day & $14^{\text {th }}$ day \\
\hline G I & $267.19 \pm 104.61(n=20)$ & $396.66 \pm 107.73^{a}(n=20)$ & $425.15 \pm 153.24^{a}(n=13)$ \\
\hline G II & $250.56 \pm 139.68(n=20)$ & $287.06 \pm 144.04^{\mathrm{b}}(\mathrm{n}=20)$ & $284.5 \pm 129.76^{b}(n=8)$ \\
\hline G III & $261.06 \pm 116.11(n=15)$ & $257.13 \pm 102.04^{b}(n=14)$ & $232.48 \pm 107.22^{b}(n=10)$ \\
\hline$P$ & $>0.05$ & $<0.05$ & $<0.05$ \\
\hline
\end{tabular}

n.s.: Non-significant $(P>0.05)$; Values with different superscripts $\left({ }^{\mathrm{a}, \mathrm{b}}\right)$ in the same row are significantly different $(P<0.05)$. 
Table 5. The alterations observed in the progesterone (P4) levels of the cows, of which the fertility parameters were calculated, with respect to the treatment period of the regressed cysts.

\begin{tabular}{|c|c|c|c|}
\hline \multirow{2}{*}{ Group } & \multicolumn{3}{|c|}{ Progesterone interval (nmol/L) } \\
\hline & $0^{\text {th }}$ day & $7^{\text {th }}$ day & $14^{\text {th }}$ day \\
\hline GI (P4个) & $5.38-22.0(\mathrm{n}=11)$ & $0.34-3.18(n=9)$ & $\leq 3.18(\mathrm{n}=2)$ \\
\hline GI (P4 $\downarrow)$ & $\leq 3.18(\mathrm{n}=9)$ & $6.18-24.63(n=6)$ & $12.0-38.6(n=3)$ \\
\hline $\mathrm{GI}+\mathrm{GI}$ & (20) & $20 / 15^{\mathrm{a}}$ & $20 / 5$ \\
\hline GII $(\mathrm{P} 4 \uparrow)$ & $>5-30(\mathrm{n}=10)$ & $0.32-3.18(n=4)$ & $\leq 3.18(\mathrm{n}=6)$ \\
\hline 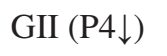 & $\leq 3.18(\mathrm{n}=10)$ & $>6-24.6(\mathrm{n}=4)$ & $>4.5-47.7(n=6)$ \\
\hline GII+GII & $(\mathrm{n}=20)$ & $20 / 8^{b}$ & $20 / 12$ \\
\hline GIII (P4 $\uparrow)$ & $6.18-32.0(n=7)$ & $\geq 3.18(\mathrm{n}=3)$ & $\geq 3.18(\mathrm{n}=4)$ \\
\hline GIII (P4 $\downarrow)$ & $\leq 3.18(\mathrm{n}=8)$ & $9.0-32.0(n=3)$ & $\geq 25(\mathrm{n}=5)$ \\
\hline GIII+GIII & $(\mathrm{n}=15)$ & $15 / 6^{\mathrm{b}, \mathrm{c}}$ & $15 / 9$ \\
\hline
\end{tabular}

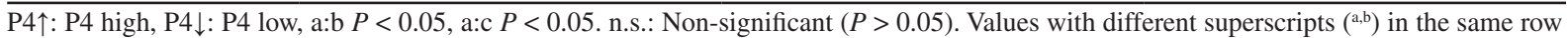
are significantly different.

\section{DISCUSSION}

One of the most common problems encountered in modern dairy production is the development of ovarian cysts. Researches have shown that the incidence of ovarian cysts in dairy herds ranges between $6 \%$ and $30 \%[25,40,42]$. In the present study, the incidence of ovarian cysts in the herd was determined to be $13.6 \%$, and thus, was found similar to the findings of the other researchers. Several factors affect the incidence of ovarian cysts, including environmental factors, season, herd management, and the age, milk yield, body condition score and uterine diseases of the animal $[11,42]$. It was reported previously, incidence of luteal cysts ranges between $15.4 \%$ and $39.85 \%$ as well as it is between $60.1 \%$ and $84.6 \%$ in follicular cysts $[19,26]$. Contrary to the above mentioned studies, the incidence of luteal cysts $(59.2 \%)$ was found to be higher than follicular cysts $(40.8 \%)$ in the present study. As it was aimed to provide uniform feeding and housing conditions, the present study was performed at a single herd. Therefore, the incidences determined for luteal and follicular cysts in the present study should be considered as specific findings valid for this particular herd.

Treatments for ovarian cyst are numerous and variable, and have changed considerably over the years [31]. Human chorionic gonadotropin (hCG) and GnRH have been used for the treatment of ovarian cysts since the 1970s [31]. Pregnancy rate obtained after GnRH treatment ranges from $67 \%$ to $87 \%$ depending on the administration dose [9]. However, Nessan et al. [30] reported a pregnancy rate of $40 \%$ with the administration of GnRH. Similarly, Probo et al. [32] reported no statistical difference between the regression rates of luteal and follicular cysts and the pregnancy rates achieved with GnRH administration. In this study, the OPR resulting from this treatment regimen was 53.3\%.

In fact, in large-sized herds, follicular and luteal cysts are not differentiated and all ovarian cysts are generally treated with GnRH and PGF $2 \alpha$ combinations [15]. It was observed that GnRH and PGF2 administrations increased the ovulation rate $(79.7 \%$ vs. $17.2 \%)$ and caused lower cystic persistence and pregnancy rates [26]. Stevenson and Tiffany [37] used Ovsynch protocol as a treatment for ovarian cysts and found it to be effective in curing the cystic condition. However, several researchers have reported low pregnancy rates around $25 \%$ to be obtained in cows treated with the Ovsynch protocol for the cows with ovarian cysts [7,28]. The differences observed in the Ovsynch protocol applications arises from the administration time of PGF $2 \alpha$ whether the progesterone level is either high or low, depending on the age of the corpus luteum $[38,44]$.

In the present study, GnRH and PGF2 $\alpha$ were administered together as a combination, and as a result of this combined use, higher percentages were obtained 
for both pregnancy rate and fertility parameters in GI and GII, in comparison to the group administered with GnRH alone (TSR was determined as $62.96 \%$ in GI, 56\% in GII and 33.3\% in GIII). The highest OPR $(85 \%)$ and FSPR (40\%) were obtained in GI. It is not possible to perform ultrasonography and test serum or milk P4 values in order to particularly establish the characteristics of the cyst (luteal or follicular) in every animal especially in large herds. Better outcome from combination therapy (GnRH and PGF2 $\alpha$ ) may be due to the fact that luteal thickening in the walls of cysts was determined by ultrasonography, but P4 values were not identified immediately and the treatments were not categorized in accord with these values. The studies also looked at P4 values not at the time of treatment but after samples were stored. In practice, since the analysis of $\mathrm{P} 4$ values immediately after the controls or parallel to these controls is not a common method, positive impact of this treatment, which is used for the possibility of both luteal and follicular cysts, on the fertility parameters indicates that it is a feasible treatment modality. In addition, a large proportion of cows with ovarian cysts treated with GnRH did not respond, probably because other follicles capable of responding to GnRH were not present [39].

No statistically significant differences were determined between GI and GII concerning the fertility parameters investigated, however numerical and proportional differences were observed. In the scope that the numbers of animals included in the study groups being close to each other, the OPR being higher and DT-PD as well as the fertility parameters such as the PI and OPI being lower in GI, revealed positive differences to have occurred in the group, which received C. TSR was higher in GI $(62.96 \%)$ than GII (56\%) and GIII (33.3\%). Additional $\beta \mathrm{C}$ adminidtration to the treatment in GI resulted in the achievement of a OPR. Similarly to the findings of a study in which $\beta C$ + PGF2 used for the treatment of ovarian disorders in dairy cows [14]. Treatments were done in first 120 days of postpartum period in this study and FSPR was found to be proportionally higher in $\beta \mathrm{C}$ administrated cows in GI. Likewise Arachiga et al. [2] reported increased pregnancy rates after $\beta C$ supplementation in heat stressed cows on day 120 postpartum.

$\beta C$ is known as an antioxidant which is eliminating the reactive oxygen species in the follicle and uterus in adequate quantities and effecting positively on reproductive status by its immunostimulator caharacter in dairy cows $[12,20]$. Several researchers have reported the reproductive performance of cows with high serum $\beta C$ levels to be higher $[6,22]$. On the other hand, some other researchers have suggested that $\beta C$ has no impact on fertility $[16,45]$. It was reported that plasma $\beta C$ levels were lower in cows with ovarian cysts [21]. Serum $\beta C$ levels increased especially after the $\beta C$ administrations on days 15 and 45 postpartum [4]. In this study, no difference were determined in the $\beta C$ levels of the cows in the groups on day 0 . On the other hand, $\beta C$ levels were significantly higher on day 7 and 14 after treatment in GI which were administered $\beta C$ additionally to the treatment protocol for ovarian cysts $(P<0.05)$. This statistical difference suggests that administration of $\beta C$ in combination therapy is also effective in the treatment of ovarian cysts.

It is indicated that in cows with low serum $\beta C$ levels, the development of the corpus luteum after oestrus occurs more slowly, formation of it is delayed, thus low production of $\mathrm{P} 4$ realized $[3,17]$. While some researchers have demonstrated that $\beta \mathrm{C}$ supplementation positively affects $\mathrm{P} 4$ levels $[3,17]$, some others have reported $\beta C$ supplementation shows no effect on the production of $\mathrm{P} 4$ [24,43]. Ay et al. [5] determined that after the administration of $\beta C$, serum $\beta C$ levels remained high for a period of approximately 14 days, and observed that this increase had no effect on the P4 levels. In the present study, the assessment of the alterations that occurred in the serum P4 levels during the treatment period of the ovarian cysts showed that no statistically significant difference existed between the study groups $(P>0.05)$. These results can be related to various factors such as season and free radicals during steroidogenesis $[3,17]$. The additional administration of $\beta C$ was determined to increase the rate of cystic regression on day 7 , when compared to the groups that were not administered with $\beta C$. This effect was attributed to the formation of the CL being supported by $\beta C$ and it is thought that the high ovarian activity after treatment, in other words the high level of cystic regression, was attributed to this combined administration.

It was found that serum P4 values increased in all treatment groups on day 7 after treatment depending on low $(<3.18 \mathrm{nmol} / \mathrm{L})$ or high $(>3.18$ $\mathrm{nmol} / \mathrm{L}$ ) pre-treatment $\mathrm{P} 4$ values. In two post-treatment 
measurements (days 7 and 14), reduced or increased post-treatment values show that administrations were effective on the ovarian activity. Although it has been shown that $\mathrm{P} 4$ values are high $(>3.18 \mathrm{nmol} / \mathrm{L})$ in luteal cysts and low $(<3.18 \mathrm{nmol} / \mathrm{L})$ in follicular cysts [29], progesterone has an indirect effect on the development of ovarian cysts [36]. Considering the fact that other than progesterone, insulin concentration and other factors such as insulin-like growth factor-1 (IGF1), luteinizing hormone (LH) and estradiol-17 $\beta$ play a more effective role in the formation of ovarian cysts [18,27], it is suggested that post-administration changes in $\mathrm{P} 4$ values in all groups are not effective on fertility parameters. The different fertility results in the groups also indicate this.

Recent researches have shown that fertility is affected by subclinical ketosis or feed and dry matter intake in lactation and closure of the energy gap [8]. In the present study, the comparison of the study groups showed that the administration of $\beta \mathrm{C}$ in addition to a GnRH + PGF2 $\alpha$ combination increased the success of the treatment regimen applied (GI 62.5\%, GII 56\% and GIII 33.3\%). Several literature reports indicate that $\beta C$ supplementation is of particular significance in dairys, where animal nutrition and green crop provision to the animals are either not done correctly or are inadequate $[1,3]$.

\section{CONCLUSIONS}

In conclusion, it was determined that high pregnancy rates were obtained by the combined treatment of ovarian cysts $(\mathrm{GnRH}+\mathrm{PGF} 2 \alpha)$ and number of inseminations per conception was at desired limits. The achievement of better percentile and numerical fertility parameters in the group, which additionally received $\beta C$, demonstrated that, particularly in farms with non-optimal animal nutrition conditions and high numbers of infertility cases, $\beta C$ supplementation could be a viable option for treatment.

\section{MANUFACTURERS}

${ }^{1}$ ECM Company. Angoulême, France.

${ }^{2}$ Alke Health Products. Istanbul, Turkey.

${ }^{3}$ Intervet Veteriner Ilaçlari. Istanbul, Turkey.

${ }^{4}$ Alvetra und Werfft AG. Neumünster, Germany.

${ }^{5}$ Duzen Laboratory Group. Ankara, Turkey.

${ }^{6}$ SPSS Inc. Chicago, IL, USA.

Acknowledgements. Authors thank to Akbel Milk and Dairy Products Inc. for providing animals and facilities.

Ethical approval. All procedures, treatments and animal care were in compliance with the guidelines of the Local Ethic Board for animal use.

Declaration of interest. The authors report no conflicts of interest. The authors alone are responsible for the content and writing of paper.

\section{REFERENCES}

1 Arbeiter K., Aslan S., \& Schwarzenberger F. 1990. Untersuchungen über die Ovarzyste beim Rind-Entstehung, Therapieerfolge, Fruchtbarkeit. Deutsche Tierarztliche Wochenschrift. 97: 380-382.

2 Aréchiga C.F., Staples C.R., McDowell L.R. \& Hansen P.J. 1998. Effects of Timed Insemination and Supplemental $\beta$-Carotene on Reproduction and Milk Yield of Dairy Cows Under Heat Stress. Journal of Dairy Science. 81(2): 390 402.

3 Aslan S., Handler J. \& Arbeiter K. 1998. Frühgravidität und embryonale bzw. Frühfetale Mortalität bei der Kuh -Gelbkörperdynamik, Progesteron, Vitamin E, Vitamin-B12, ß-Carotin und Folsäurekonzentrationen im peripheren Blut. Wiener Tierärztliche Monatsschrift. 85: 141-147.

4 Ay S.S., Kaya D., Kucukaslan I., Agaoglu A.R., Emre B., Handler J., Findık M. \& Aslan S. 2012. Beneficial effects of Beta-carotene injections prior to treatment with PGF2 $\alpha$ on the fertility of postpartum dairy cows. Revue de Médecine Vétérinaire. 163(8-9): 387-392.

5 Ay S.S., Kucukaslan I., Kaya D., Mulazımoglu S.B., Emre B., Kacar C., Kalender H., Findık M., Bollweın H., Rıegler M., Schäfer-Somı S., Scholbach J. \& Aslan S. 2012. The Change in Luteal Blood Flow and Luteal Size after Beta Carotene and GnRH Injections in Early Pregnant Dairy Cows. Kafkas Üniversitesi Veteriner Fakültesi Dergisi. 18(6): 1035-1041.

6 Ayasan T. \& Karakozak E. 2010. Hayvan Beslemede $\beta$-Karoten Kullanılması ve Etkileri. Rev1ew. Kafkas Üniversitesi Veteriner Fakültesi Dergisi. 16(4): 697-705.

7 Bartolome J.A., Archbold L.F. \& Morresey P. 2000. Comparison of synchronization of ovulation and induction of oestrus as therapeutic strategies for bovine ovarian cysts in the dairy cows. Theriogenology. 53(3): 815-825. 
8 Baştan A. \& Gürbulak K. 2015. Metabolic Disorders. In: Semacan A., Kaymaz M., Fındık M., Rişvanlı A. \& Köker A. (Eds). Obstetric and gynecology in farm animal. Malatya: Medipres Turkey, pp.331-363.

9 Bierschwal C.J., Garverick H.A., Martin C.E., Youngquist R.S., Cantley T.C. \& Brown M.D. 1975. Clinical response of dairy cows with ovarian cysts to GnRH. Journal of Animal Science. 41(6): 1660-1665.

10 Bindas E.M., Gwazdauskas F.C., McGillard M.L. \& Polan C.E. 1984. Progesterone responses to Human Chorionic Gonadotropin in dairy cattle supplemented with $\beta$-carotene. Journal of Dairy Science. 67(12): 2978-2985.

11 Cattaneo L., Signorini M.L., Bertoli J., Bartolome J.A., Gareis N.C., Diaz P.U., Bo G.A. \& Ortega H.H. 2014. Epidemiological Description of Cystic Ovarian Disease in Argentine Dairy Herds: Risk Factors and Effects on the Reproductive Performance of Lactating Cows. Reproduction in Domestic Animals. 49(6): 1028-1033.

12 Chew B.P. 1993. Role of carotenoids in the immune response. Journal of Dairy Science. 76: 2804-2811.

13 Çelik H.A., Avcı G., Aydın İ., Bülbül A. \& Bülbül T. 2009. Effect of $\beta$-carotene on ovarium functions and ovsynch success in repeat breeder cows. Kafkas Üniversitesi Veteriner Fakültesi Dergisi. 15(1): 87-94.

14 Dovenski T., Trojacanec P., Kochoski L.J., Petkov V., Popovski K. \& Trojacanec S. 2007. Efficiency of Beta-Carotene for treatment of ovarian disorders in dairy cows. Reproduction of Domestic Animals. 42: 116.

15 Garverick H.A. 1999. Ovarian follicular dynamics and endocrine profiles in cows with ovarian follicular cysts. In: Howard J.L. \& Smith R.A. (Eds). Current Veterinary Therapy, Food Animal Practice. Philadelphia: WB Saunders Co., pp.577-580.

16 Gossen N. \& Hoedemaker M. 2005. Effect of beta-carotin serum concentration on the reproductive performance in dairy cows. Berliner und Munchhener Tierarztliche Wochenschrift. 118(7-8): 326-33.

17 Graves-Hoagland R.L., Hoagland T.A. \& Woody C.O. 1988. Effect of $\beta$ carotene and vitamin A on progesterone production by bovine luteal cells. Journal of Dairy Science. 71(4): 1058-1062.

18 Gumen A. \& Wiltbank M.C. 2002. An alteration in the hypothalamic action of estradiol due to lack of progesterone exposure can cause follicular cysts in cattle. Biology of Reproduction. 66: 1689-1695.

19 Gundling N., Drews S. \& Hoedemaker M. 2015. Comparison of Two Different Programmes of Ovulation Synchronization in theTreatment of Ovarian Cysts in Dairy Cows. Reproduction of Domestic Animals. 50(6): 893-900.

20 Ikeda S., Kitagawa M., Imai H. \& Yamada M. 2005. The roles of vitamin A for cytoplasmic maturation of bovine oocytes. Journal of Reproduction and Development. 51(1): 23-35.

21 Inaba T., Mezan M., Shimizu R., Nakano Y. \& Mori J. 1986. Plasma Concentrations of $\beta$-Carotene and Vitamin A in Cows with Ovarian Cyst. The Japanese Journal of Veterinary Science. 48(6): 1275-1278.

22 Iwa ska S., Lewicki C. \& Rybicka M. 1985. The effect of beta carotene supplementation on the beta carotene and vitamin A levels of blood plasma and some fertility indices of dairy cows. Archiv Fur Tierernahrung. 35(8): 563-70.

23 Jou P., Buckrell B.C., Liptrap R.M. \& Summerlee A.J.S. 1999. Evaluation of the effect of GnRH on follicular ovarian cysts in dairy cows using transrectal ultrasonography. Theriogenology. 52(5): 923-937.

24 Kaewlamun W., Okuyi M., Humblot P., Techakumphu M. \& Ponter A.A. 2011. Does supplementing dairy cows with $\beta$-carotene during the dry period affect postpartum ovarian activity, progesterone, and cervical and uterine involution? Theriogenology. 75(6): 1029-1038.

25 Kesler D.J. \& Garverick H.A. 1982. Ovarian cysts in dairy cattle: a review. Journal of Animal Science. 55(5): 11471159 .

26 Lopez-Gatius F. \& Lopez-Bejar M. 2002. Reproductive performance of dairy cows with ovarian cysts after different GnRH and cloprostenol treatments. Theriogenology. 58(7): 1337-1348.

27 Lucy M.C., Beck J., Staples C.R., Head H.H., De La Sota R.L. \& Thatcher W.W. 1992. Follicular dynamics, plasma metabolites, hormones and insulin-like growth factor I (IGF-I) in lactating cows with positive or negative energy balance during the preovulatory period. Reproduction Nutrition Development. 32: 331-341.

28 Meyer J.P., Radeliff R.P., Rhoads M.L., Bader J.F., Murphy C.N. \& Lucy M.C. 2007. Timed artificial insemination of two consecutive services in dairy cows using prostaglandin F2-alpha and gonadotropin-releasing hormone. Journal of Dairy Science. 90(2): 691-698.

29 Nakao T., Sugihashi A., Saga N., Tsunoda N. \& Kawata K. 1983. Use of milk progesterone enzyme immunoassay for differential diagnosis of follicular cyst, luteal cyst and cystic corpus luteum in cows. American Journal of Veterinary Research. 44: 888-890. 
30 Nessan G.K., King G.J., McKay G.W., Thomson J.D. \& Bertrand W. 1977. Treatment of cystic ovarian degeneration in dairy cows with gonadotropic releasing hormone or human chorionic gonadotropic hormone. Canadian Veterinary Journal. 18(2): 33-37.

31 Peter A.T. 2004. An update on cystic ovarian degeneration in cattle. Reproduction in Domestic Animals. 39(1): 1-7.

32 Probo M., Comin A., Mollo A., Cairoli F., Stradaioli G. \& Veronesi M.C. 2011. Reproductive performance of dairy cows with luteal or follicular ovarian cysts after treatment with buserelin. Animal Reproduction Science. 127(3-4): 135-139.

33 Santos J.E., Huber J.T., Theurer C.B. Nussio C.B., Nussio L.G., Tarazon M. \& Fish D. 2000. Effects of grain processing and bovine somatotropin on metabolism and ovarian activity of dairy cows during early lactation. Journal of Dairy Science. 83(5): 1004-1015.

34 Schweigert F.J., Engalbert F., Mothes R., Hurtıenne A. \& Immıg I. 2007. Cooperative European study for the validation of a novel cow-side $\beta$-carotene assay in serum and blood. In: Program of 13th International Conference on Production Disease in Farm Animals (Leipzig, Germany). p.162.

35 Sheldon I.M. \& Noakes D.E. 1998. Comparison of three treatments for bovine endometritis. Veterinary Record. 142(21): 575-579.

36 Silvia W.J., Hatler T.B., Nugent A.M. \& Laranja da Fonseca L.F. 2002. Ovarian follicular cysts in dairy cows: An abnormality in folliculogenesis. Domestic Animal Endocrinology. 23: 167-177.

37 Stevenson J.S. \& Tiffany S.M. 2004. Resychronizing estrus and ovulation after not- pregnant diagnosis and various ovarian states including cysts. Journal of Dairy Science. 87(11): 3658-3664.

38 Taponen J., Katila T. \& Rodríguez-Martínez H. 1999. Induction of ovulation with Gonadotropgin-Releasing Hormone during proestrus in cattle: Influence on subsequent follicular growth and luteal function. Animal Reproduction Science. 55(2): 91-105.

39 Tebble J.E., O'Donnell M.J. \& Dobson H. 2001. Ultrasound diagnosis and treatment outcome of cystic ovaries in cattle. Veterinary Record. 148(13): 411-413.

40 Teshome E., Kebede A., Abdela N. \& Ahmed W.M. 2016. Ovarian Cyst and its Economic Impact in Dairy Farms: A Review. Global Veterinaria. 16(5): 461-471.

41 Thienpont L.M., Verhseghe P.G., Van Brussel K.A. \& De Leenheer A.P. 1998. Efforts by industry toward standardization of serum estradiol-17 $\beta$ measurements. Clinical Chemistry. 44(3): 671-674.

42 Vanholder T., Opsomer G. \& De Kruif A. 2006. Aetiology and pathogenesis of cystic ovarian follicles in dairy cattle: a review. Reproduction Nutrition Development. 46(2): 105-119.

43 Weng B.C., Chew B.P., Wong T.S., Park J.S., Kim H.W. \& Lepine A.J. 1999. $\beta$-Carotene uptake and changes in ovarian steroids and uterine proteins during the estrous cycle in the canine. Journal of Animal Science. 78(5): 12841290.

44 Wiltbank M.C. \& Pursley J.R. 2014. The cow as an induced ovulator: Timed AI after synchronization of ovulation. Theriogenology. 81(1): 170-185.

45 Yıldız H., Kaygusuzoğlu E. \& Kızıl Ö. 2005. Serum progesterone, vitamin A, E, C and $\beta$-carotene levels in pregnant and nonpregnant cows post-mating. Journal of Animal and Veterinary Advances. 4(3): 381-384.

46 Youngquist R.S. 1986. Cystic follicular degeneration in the cow. In: Morrow D.A. (Ed). Current Therapy in Theriogenology. 2nd edn. Philadelphia: WB Saunders Co., pp.243-246. 